\title{
HOW COVID-19 OUTBREAK PANDEMIC PROVOKES INDUSTRIALACTIVITY ALTERATION IN KARAWANG
}

\author{
Aina Nindiani ${ }^{1}$, Afif Hakim ${ }^{2}$, Dicky \\ Suryapranatha $^{3}$,Aris Insan Waluya ${ }^{4}$, Amelia Nur \\ Fariza $^{5}$ \\ ${ }^{1-5}$ Jurusan Teknik Industri, Fakultas Teknik dan Ilmu Komputer, Universitas Buana Perjuangan \\ KarawangJl. HS. Ronggowaluyo Telukjambe Timur Karawang, \\ Email: aina.nindiani@ubpkarawang.ac.id
}

\begin{abstract}
In early 2020, COVID-19 was present and changed the socio-economic order of the community. All sectors were affected as well as industrial sectors for both manufacturing and services. The business' operation has changed to comply with health protocols to prevent the spread of the coronavirus. The impacts of the COVID-19 in the industry identified in this study were decreased income, supply chain disruption, the onset of free time at work, and implementation of health protocols. This impact caused changes in activities in the form of reduced working hours, reduction of workers, material and process efficiency, increased lead time and delays in distribution, physical distancing, activities to prevent exposure to COVID-19, disinfection activities in companies, early detection of COVID19, and increased employee immunity. Strategies that can be carried out are building a commitment to maintaining discipline in implementing health protocols, utilizing digital technology (internet of things) to expand the market, and implementing a lean strategy to achieve efficiency or save resources.
\end{abstract}

Keywords: COVID-19; industry; efficiency; lean; digital technology

\begin{abstract}
ABSTRAK
Hadirnya COVID-19 di awal tahun 2020 telah mengubah tatanan sosial ekonomi masyarakat. Seтиa sektor terpengaruh salah satunya sektor industri, baik manufaktur maupun jasa. Operasi bisnis telah berubah untuk mematuhi protokol kesehatan untuk mencegah penyebaran virus corona. Dampak COVID-19 pada industri yang diidentifikasi dalam penelitian ini adalah penurunan pendapatan, gangguan rantai pasok, timbulnya waktu luang di tempat kerja, dan penerapan protokol kesehatan. Dampak tersebut menyebabkan perubahan aktivitas berupa pengurangan jam kerja, pengurangan pekerja, efisiensi material dan proses, peningkatan lead time dan keterlambatan distribusi, pengaturan jaga jarak, aktivitas pencegahan paparan COVID-19, aktivitas desinfeksi di perusahaan, deteksi dini COVID-19, dan meningkatkan kekebalan karyawan. Strategi yang dapat dilakukan adalah membangun komitmen untuk menjaga kedisiplinan dalam menerapkan protokol kesehatan, memanfaatkan teknologi digital (internet of things) untuk memperluas pasar, dan menerapkan strategi lean untuk mencapai efisiensi atau penghematan sumber daya.
\end{abstract}

Keywords: COVID-19; Industri; efisiensi; lean; digital technology

\section{INTRODUCTION}

The COVID-19 outbreak in early 2020 in Indonesia was shocking. It was never expected that the world would experience an epidemic that would significantly affect the socio-economic 
order today. Starting from Wuhan (China), COVID-19 has infected various parts of the world, including Indonesia. Indonesia is still experiencing the coronavirus pandemic with an increasing curve. One hundred eleven thousand four hundred fifty-five coronavirus cases were recorded in Indonesia, with deaths reaching 5,236 people based on data updated on August 2, 2020 (Wordometers, 2020). Indonesia is even at the highest rate in Southeast Asia for total cases, active cases, and total deaths.

This coronavirus pandemic has an impact on health and affects all aspects of people's lives. The industrial sector has also been affected by the COVID-19 pandemic. Business sustainability is vulnerable due to the human element as a source of driving force for businesses that become the target of this disease. From along the supply chain, from upstream to downstream, feel the impact of this pandemic. Some industries even have to stop their operational activities because they are no longer able to pay their employees due to slumping demand and various obstacles such as difficulties in procuring raw materials.

Some industries sent home their employees, and some even apply layoffs. Fig 1 shows the number of workers who were sent home and laid off based on data from the Disnakertrans Jawa Barat (May 20, 2020). The impact of COVID-19, which affects human health, must receive special attention in company operations, and a strategy is needed to bounce back for business sustainability.

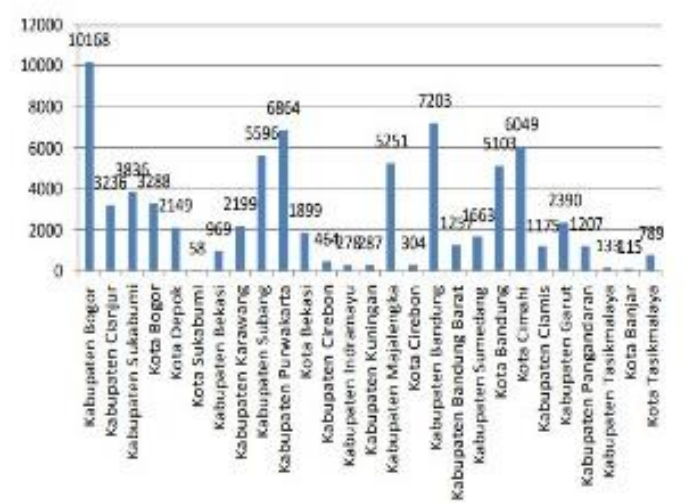

a

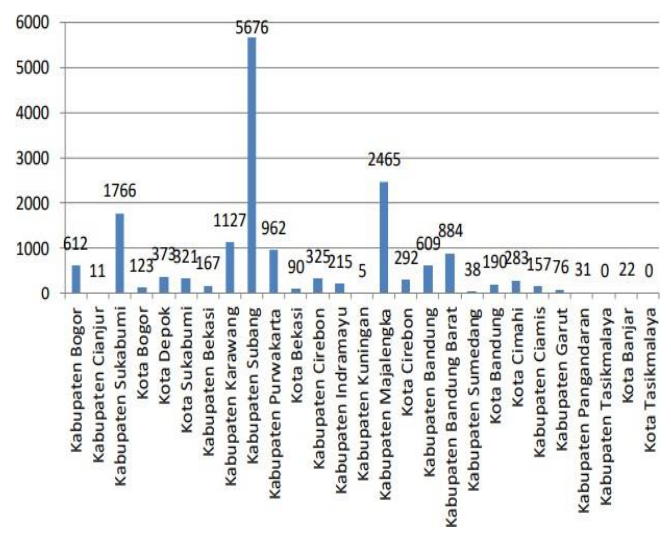

b

Fig 1 a. Number of workers sent home in West Java;

b. Number of laid-off workers in West Java

Source: Disnakertrans Jawa Barat, data processed (May 20, 2020)

The global COVID-19 pandemic analyzed by several researchers such as Laing (2020) exposed that the COVID-19 pandemic caused infections and deaths and wreaks havoc on the global economy. COVID-19 has the potential to destroy the livelihoods of individuals, businesses, industries, and entire economies. Nor is the mining sector immune to these impacts, and the crisis has the potential to have severe consequences in the short, medium, and long term for the industry. Chauhan \& Singh (2020) explained air quality related to COVID-19. The PM2.5 analysis results stated that the main cities (New York, Los Angeles, Zaragoza, Rome, Dubai, Delhi, Mumbai, Beijing, and Shanghai) were affected by all social distancing restrictions showed a decrease in PM2.5 concentrations. The low concentration of PM2.5 reflected the improvement of air quality in the city and indicated that mobility was being restricted to reduce the spread of COVID-19. Likewise with Zambrano-Monserrate (2020) investigated the impact of COVID-19 on the environment in China, the United States, Italy, and Spain. The study showed a significant relationship between contingency measures and improved air quality, clean beaches, and environmental noise reduction.

On the other hand, there were negative aspects such as reducing recycling and increasing waste, which endangers the pollution of physical space (water and land), apart from air. Sobieralski (2020) analyzed the effect of uncertainty shocks on airline jobs concerning the global 
pandemic COVID-19. The aviation industry has faced many threats throughout history, but none as rapid or severe as the one caused by the spread of COVID-19. A reduction in capacity amid increasing travel restrictions had an impact on the airline workforce. Recovery after uncertainty shocks was estimated to take between 4 and 6 years.

This study aimed to identify the impact and changes in activities in the manufacturing/service industry in the Karawang Regency as a result of the COVID-19 outbreak pandemic and its business recovery strategies.

\section{RESEARCH METHOD}

This research was conducted by taking data samples from manufacturing/service industry workers in Karawang to see changes in workplace activities due to COVID-19 and worker behavior related to health protocols. The questionnaire data collection was carried out on randomized manufacturing/service industry workers by distributing questionnaires in May-June 2020.

In the $1^{\text {st }}$ stage of the survey, electronic questionnaires were distributed to workers in the manufacturing/service industry domiciled in Karawang. The distribution of electronic questionnaires was carried out because, in a pandemic situation, it was not possible to do it face to face. The questionnaires distributed were qualitative to get an overview of activity changes, especially regarding the health protocol carried out by the industrial world in Karawang in due to the COVID-19 pandemic and related to worker behavior to health protocols. In the $2^{\text {nd }}$ stage of the survey, electronic questionnaires were distributed with open questions to obtain in-depth information about the impact of COVID-19 in the manufacturing/service industry, primarily related to quality management.

Sampling was carried out based on the Yamane formula (Israel, 1992). Based on the economic census of Central Bureau of Statistics in 2016 results conducted in Karawang Regency, there were 233,606 non-agricultural business units/companies in the scale of micro, small, medium, and large enterprises. If this data is considered a population, the sampling carried out is probability sampling using simple random sampling. Thus, the required sample with a clearance of $10 \%$ will require a minimum of 100 samples for the survey. In qualitative research, the data validity test is the credibility test, carried out by increasing persistence by reading references and research results related to the findings studied (Sugiyono, 2017). Triangulation of the research instrument was carried out by crosschecking with the circular letter of Minister of Industry No. 4 of 2020 \& Minister of Health No. HK.02.01 / MENKES / 335/2020. The transferability test is stated in the preparation of a clear and detailed report so that the reader understands the research results. The dependability test and confirmability test were intended to ensure that this research was properly carried out. There was a process until results were obtained.

\section{RESULT AND DISCUSSION}

In the $1^{\text {st }}$ stage of the survey, 278 data were obtained, and this was sufficient because the required sample was 100 samples. Respondents who work in manufacturing companies were 229 people, and service companies were 49 people. Profiles of survey respondents in the $1^{\text {st }}$ stage were shown in Appendix 1. This quetionnaires were distributed using simple random sampling technique to workers in the manufacturing and service industries. In the manufacturing industry, most respondents worked in large enterprises, while in the service industry, it was more evenly distributed across the four industrial scales. The types of manufacturing industries surveyed were the automotive industry (including spare parts such as car seats, bolts, die casting, pistons, fasteners, injection molding, and so on), electronics, consumer goods, food/beverages, textiles, garments, batteries, plastics, polymers, cigarettes, flavor \& fragrance, steel, chemicals, mints, and metals. The types of service industry respondents surveyed were public services, laundry, bookstores, food trade, textile trade, service outsourcing, property, tourism, palm oil distributors, retail, telecommunications, wasted cooking oil exports, hospitals, culinary, banks, contractors, schools, pharmacy, dangerous waste treatment, courses, warehousing, logistics, finance, and rest 
area.

The graphs of the $1^{\text {st }}$ stage electronic questionnaire results were shown in Appendix 1 . Question no. 1 to no. 15 asked about the readiness of companies during the COVID-19 pandemic. This pandemic has prompted the company to make various changes to activities that were not previously carried out, primarily related to health protocols in the workplace. Judging from the aspect of Total Quality Management (TQM), this is a form of improving the quality of service from the company in order to create safe working conditions for internal customers (namely workers themselves) so that they can work well to achieve external customer satisfaction. TQM itself is a quality-based management approach that involves all members of the organization to achieve customer satisfaction. Therefore, changes in activities in the company regarding the COVID-19 pandemic must be supported by all personnel. Healthy workers will be able to contribute to creating a work environment that is conduciveto making a good quality product or service. Meanwhile, question no. 16 and 17 asked workers' behavior related to the COVID-19 pandemic. The changes in activities related to the health protocol in the companies are:

1. The body temperature is checked in the workplace before entering the company's premises.

2. Companies/agencies check for cough/flu/shortness of breath symptoms before entering the working area.

3. If there are unwell workers, they will be recommended to go to a health facility.

4. The company where they work informs via notification at the entrance area for workers who have a history of travel from a country or zone/city with local transmission of COVID- 19 within 14 days of not entering the company area.

5. Air circulation in the workplace area.

6. The company provides adequate facilities for washing hands (with soap and running water), including facilities for washing hands before entering the building.

7. The company provides adequate alcohol-based hand sanitizers.

8. The company provides adequate masks, gloves, and clothing that ensures workers' safety and the products produced.

9. The company regularly conducts area cleaning using disinfectants in public areas such as bathrooms, registration counters, payments, dining areas, and others, especially during peak hours of activities.

10. The company limits workers' number when using public facilities such as places of worship, canteens, and toilets.

11. The company provides supplements and nutritious food for all workers.

12. The company provides guidance for workers from workers leaving residence to returning to their homes.

13. The company participates in socializing clean and healthy living habits and information about COVID-19 through the installation of banners/graphic info at strategic places in the work area.

14. The company asks workers to maintain a minimum distance (physical distancing) of 1 meter (including prohibiting groups of people during break time).

15. The company uses a partition (barrier) such as plastic or other materials (especially if it is not possible to do physical distancing in the work area).

16. Workers wear masks from the time they leave the house and when they are in the work area.

17. Workers have implemented a clean and healthy lifestyle, such as washing their hands regularly using water and soap or alcohol-based hand washing and not touching unnecessary face areas.

18. The workplace prohibits shaking hands with fellow workers and adopts other alternative forms of greeting.

19. The workplace applies work from home for certain parts of sections.

In general, the questionnaire results in the manufacturing and service industries have carried out all the asked conditions in the question. Still, the frequency of implementation is different between the manufacturing and the service industry.

In the $2^{\text {nd }}$ stage of the survey, 113 industrial worker respondents in Karawang filled out 
the questionnaire. The second stage of the survey aimed to obtain in-depth information about changes in quality management activities due to COVID-19 by providing open questions so that respondents can freely provide answers. Quality is defined as a dynamic condition that affects products, services, people, processes, and the environment that meet or exceed expectations (Goetsch \& Davis, 2013). In the $2^{\text {nd }}$ stage of the survey, open questions were asked about changes in company activities during the COVID-19 pandemic compared to before the pandemic. Based on the empirical results of questionnaires distributed, the presence of COVID-19 has caused changes in industrial activity that synthesized in Table 1.

Table 1. Impacts and Industrial Activity Alterations in Karawang provoked by COVID-19.

\begin{tabular}{|c|c|c|}
\hline No & Impacts & Activity Alteration \\
\hline 1 & Decreased Income & $\begin{array}{l}\text { Reduction of working / production hours: } \\
-\quad \text { Reduction of shifts from } 3 \text { shifts to } 2 \text { shifts } \\
-\quad \text { Reduced working hours per day (1 hour) } \\
-\quad \text { Reduction of service hours } \\
\text { Reduction of workers: } \\
-\quad \text { Workers are reduced so the completion of the work } \\
\quad \text { takes longer } \\
\text { - Layoff } \\
\text { Material and process efficiency: } \\
-\quad \text { Use of cheaper alternative raw materials } \\
-\quad \text { Reduction of product (food) weight to reduce price for } \\
\quad \text { increasing sales }\end{array}$ \\
\hline 2 & Supply Chanin Disruption & $\begin{array}{l}\text { Delayed distribution: } \\
\text { - } \text { Export / import was late } \\
\text { - } \text { Increased lead time because raw materials were } \\
\text { difficult, so the supply of raw materials were increased } \\
\text { (from once a week to once a month), becoming over } \\
\text { stock } \\
\text { - Delivery of goods was hampered by large-scale social } \\
\text { restrictions (PSBB), so they have to find new routes }\end{array}$ \\
\hline 3 & $\begin{array}{l}\text { The Onset of Free Time at } \\
\text { Work }\end{array}$ & $\begin{array}{l}\text { Human resource competency improvement: } \\
-\quad \text { Refreshment training for workers } \\
\text { Increase production support activities: } \\
-\quad \text { Longer checking of product quality } \\
-\quad \text { Increase Maintenance } \\
-\quad \text { Increase checking materials in the warehouse }\end{array}$ \\
\hline 4 & Health Protocols & $\begin{array}{l}\text { Physical Distancing: } \\
\text { - Digital transaction implementation } \\
\text { - } \text { A queue system that provides distance } \\
\text { - } \text { The use of partitions } \\
\text { - } \quad \text { Public facilities provide distance (canteen, places of } \\
\text { worship, shuttle bus) } \\
\text { - } \quad \text { Virtual meetings or online coordination } \\
\text { - } \\
\text { - } \quad \text { Weduce briefing } \\
\text { - Work From Home } \\
\text { - } \quad \text { Avoid Crowds } \\
\text { Prevention of exposure to COVID-19: } \\
\text { - Wear PPE (Mask, Face Shield, Gloves, Hat) according } \\
\text { - to the needs } \\
\text { - No prayer mats are provided in places of worship } \\
\text { - Worker attendance recording with id tapping (replacing } \\
\quad \text { finger print) }\end{array}$ \\
\hline
\end{tabular}




\begin{tabular}{ll}
\hline No Impacts & \multicolumn{1}{c}{ Activity Alteration } \\
\hline & - Reduction inspection of imported material to prevent \\
& contamination \\
& Disinfection Activities: \\
& - Provision of handwashing fascilities with soap and \\
& running water \\
& - Provision of hand sanitizer \\
& - Sterile working equipment, sprayed with anti-virus \\
& - Environmental cleaning with a disinfectant \\
Early detection: & - Checking of body temperature \\
& - Rapid test \\
& - Daily sharelock obligations \\
& - Self-isolation after traveling from the danger zone \\
Increased immunity: & - Provision of vitamin C or multivitamins \\
- & Provision of nutritious food \\
& -10 minutes of sunshine exposure in the company \\
\hline
\end{tabular}

\section{Industrial Activity Alteration Affected by COVID-19}

In the second stage of the questionnaire, in-depth information was obtained about changes in industrial activities affected by COVID-19. At an automotive company in Karawang, this pandemic outbreak caused an overstock. This phenomenon occurs due to the company's concern that there will be a lockdown at that time. The stock of goods in materials, WIP, and finished goods, mostly metal, has increased. This increases the risk of becoming corroded. The strategy taken is to store parts in boxes that use anti-rust plastic, provide anti-rust fluid to the parts, provide anti-rust paper in each box, wrapping each box if the goods will not be processed for a long time, and making adjustments to the production process.

In other automotive companies, more frequent checking of the goods are made in the warehouse. Previously, it was checked every six months because the product was sent every day to the customer, so there was no production accumulation in the warehouse. However, during a pandemic, because there is almost no product delivery to the customer, it is checked every month to determine the occurrence of rust on the product.

In one of the car parts company, before the pandemic, employees worked as usual, and overtime was often held from morning to night shifts because there were many orders from customers. After the pandemic conditions changed, such as the admission schedule was divided into two sessions only, session one worked on Monday, Wednesday, Friday, and session two worked on Tuesday and Thursday. Every week the schedule is rolled in, and the workers get the Work from Home (WFH) by doing online attendance from home. WFH is carried out to maintain distance and keep employees working because, in pandemic conditions, there are prone to the employee reduction. Besides, due to decreased production, employees become unproductive at work. This condition was utilized by the company to double-check the products so the quality of the products are better in consumers' eyes (workers helped in checking their friends' work).

Regarding quality management, the company maintains product quality as much as possible. What has changed is the quality management related to the health of the employees. This is because, during the COVID-19 pandemic, the company implemented strict health protocols, such as 1). When entering the company, body temperature is checked; 2). Prohibition or appeals not to go to the hometown; 3). Implementation of rapid test for employees who have traveled far (outside the city); 4). Self-isolation for employees who travel on business for working purposes; 5). Provision of vitamins, masks, and hand sanitizers in the workplace. The use of Personal Protective Equipment (PPE) in the production room was also tightened. Prior to COVID19 , operators on the production line only used specified PPE such as gloves, masks, and hats, but 
after COVID-19, several companies required operators to use face shields.

At one of the pharmaceutical companies, there has been a tightening of the rules that have been enforced since the COVID-19 pandemic. All employees are asked to do a rapidtest (new \& old employees), check their body temperature before entering the work area, change their uniforms, hats, masks every day. Every shift is carried out by sanitizing using alcohol. (previous only conducted in daily basis using non-alcohol chemical). Besides, the company reduces production hours (but working hours are still the same) so that there are no meeting sessions between shifts. The insulated canteen is 1 meter per person. Additional vitamin $\mathrm{C}$ is given when eating in the canteen, and good manufacturing of drugs (CPOB) training is provided to replace the reduced production hours. The workspace can only be occupied by three workers using face shield. Places of worship are isolated and allowed to bring individual praying mat.

The presence of COVID-19 had a positive impact on companies. Compared to the condition before the pandemic occurred, the quality of the company's environment was very poorly maintained. There were many places where they were not given much attention, such as canteens, prayer rooms/mosques, and company meeting rooms. After the existence of COVID-19, the quality of the environment has been further improved, starting from the provision of a handwashing facilities in every corner of the room and the provision of hand sanitizer in several areas with the high potential of crowds.

System enforcement of the work from home in the section allows it to be carried out under each division's policies in the company. Minimizing activities that require the use of hands/limbs in public facilities are also implemented as much as possible, such as opening doors and carrying out abscesses, only using ID card tapping. Previously, attendance was carried out using fingerprint. The negative impact of the COVID-19 pandemic was the quality of distance communication between subordinates and superiors. It was because superiors rarely visited subordinates in the field. The quality of the relationship between subordinates and superiors become less harmonious and often caused missed communication.

In a service company, electronic retailer that always pay attention to the quality and convenience of customers who come, especially in product service and shipping services, carry out the cleaning of all area of the office and products. However, this company had temporarily closed the shop as recommended by the government. Reduction of employees was also carried out due to lower sales turnover. During the pandemic, office cleaning was carried out more frequent to prevent transmission of the virus and provide additional facilitiesin the form of tissues, hand sanitizers, and masks while working.

In a food company, strict supervision of the food production process' cleanliness was carried out, starting from the supply of raw materials from suppliers to the food distribution process. The health of employees was seriously paid attention by conducting routine temperature and other health checks. The changes occurred in the COVID-19 pandemic in one of the clean water providers was decreasing the number of clean water consumption, which resulted in a decline in company profits. This has led stakeholders to lower the clean water quality standard to a figure close to the lower limit. Before the COVID-19 pandemic occurred, the quality standards produced from the clean water treatment process were close to the upper limit of quality standards (i.e., making very good quality). Stakeholder requests to save costs by reducing operational costs in minimizing the use of chemicals in the clean water treatment process.

In public services in Karawang, service operating hours have been reduced, from the beginning before the pandemic, providing services at $08.00-15.00$ WIB. During the pandemic shorter service hours provided at $08.00-12.00$ WIB. Health protocols were also closely guarded because of a hub for crowds.

\section{Recovery Strategies}

This research was conducted from May to June 2020. The first stage of the survey results were quite good regarding the implementation of health protocols in the manufacturing/service industry in Karawang. But until the end of 2020, this pandemic has not ended and still shows a positive case curve for COVID-19 with an increasing trend. Therefore a strategy is needed to be able to get back to the normal condition. The strategy that can be implemented is building a strong commitment to maintain high discipline in implementing health protocols to prevent the 
pandemic's spread. This strategy aims to protect human resources as a driving asset for the company's business.

The impact of COVID-19 reduces company profits. Therefore efficiency can be made to save costs. Kumar et al. (2014) stated that India's manufacturing sector struggles to generate revenue, depending on two aspects, namely reducing production costs and improving product quality to meet customer requirements. Regarding services, Tortorella et al. (2020) examined the impact of the COVID-19 pandemic and related work implications in the relationship between lean implementation and service performance. The results show that organizations that have implemented lean services more extensively have benefited more from the impact of COVID-19 in the work environment. Social distancing does not mediate the effect of lean service on delivery quality and performance. Lean is a production process that includes resources to achieve goals and create value through waste elimination. Therefore, the lean strategy can be a step considered to accelerate recovery.

A lean strategy is an embodiment of the principle of lean thinking where value is generated effectively and efficiently in the entire production system with a focus on customers (Thangarajoo \& Smith, 2015). The basic concept of lean thinking is waste elimination and value creation (Ramezani \& Mahdloo, 2014). Whereas eliminating waste along the value stream will create processes that require less human effort, less space, less capital, and less time to produce products and services at less cost with fewer defects than traditional business systems (lean enterprise institute in Kiran, 2017). Production can be carried out at the right amount, at the right quality, and at the right time by saving resources through waste elimination in the system.

The next strategy is taking advantage of digital industry 4.0 technology. Javaid et al. (2020) stated that industrial technology 4.0 could provide benefits in the health sector's service industry by detecting and diagnosing COVID-19 and other symptom-related problems. Industry 4.0 can gather information for the health care system on the right COVID-19 patients, such as providing daily updates of infected patients by area, age, and state. Industrial technology 4.0 can offer many innovative ideas and solutions to deal withmedical emergencies both locally and globally.

COVID-19 affects workers' health and the more important for companies in the economic factor is generating revenue. Physical distancing should not be responded to give up on circumstances. The company must be able to find a way to get demand from customers. Therefore, the use of industrial technology 4.0 is now a necessity, mainly because the pandemic has not ended, and physical distancing must always be maintained. Using digital technology such as the internet of things makes the industry develop its capabilities, especially developing a more comprehensive marketing network. Today's consumers prefer to make purchases or online transactions to prevent themselves from being exposed toCOVID-19. This opportunity should be used by the manufacturing/service industry to create demand. Especially for large-scale enterprises (the greatest number of the respondents in this study) are required to be creative and innovative to get customer demand. It is different for the micro, small and medium industries (MSME), which need to get assistance from the government in the form of funds and support to continue production. But of course, creativityand innovation are needed by all industrial scales to sustain their business.

\section{CONCLUSIONS}

The COVID-19 pandemic has various impacts on the manufacturing and service industries. There are four identifiable impacts of COVID-19 on the manufacturing/service industry: decreased income, disruption of supply chains, the onset of free time at work, and implementation of health protocols. This impact causes changes in activities in reduction of working hours, reduction of workers, material and process efficiency, increased lead time and delayed in distribution, physical distancing, activities to prevent exposure to COVID-19, and disinfection activities companies, early detection of COVID-19, and increased employee immunity.

A strategy that can be done is to build a commitment to maintaining discipline in implementing health protocols to protect human resources as an asset that drives its business. The 
use of digital technology (internet of things) can be done as a strategy to expand the market. A lean strategy can be done to achieve effectiveness and efficiency by reducing the waste in the system to support the continuity of industrial business processes.

This research proposes recovery strategies as implications for industries in the COVID-19 pandemic era. By implementing discipline habbit to maintain health protocols, striving to run the operations with creativity and innovation to obtain demand, and perform efficiency, the industries will be able to achieve the business continuity.

\section{Acknowledgments}

The authors are grateful to Buana Perjuangan University (UBP Karawang), who has funded this research. The authors also thank Gusti Pratama and Novita Rahmasari, who helped in distributing the research questionnaires.

\section{REFERENCES}

Chauhan, A. \& Singh, R.P. (2020). Decline in PM2.5 concentrations over major cities around the world associated with COVID-19. Environmental Research. https://doi.org/10.1016/j.envres.2020.109634

Goetsch, D. L. \& Davis, S.B. (2013). Quality Management for Organizational Excellence, Introduction to Total Quality. Seventh Edition. New Jersey: Pearson Education, Inc.

Israel, G.D. (1992). Determining sample size. Institute of Food and Agriculture Sciences, University of Florida.

Javaid, M., Haleem, A., Vaishya, R., Bahl, S., Suman, R., \& Vaish, A. (2020). Industry 4.0 technologies and their applications in fighting COVID-19 pandemic. Diabetes \& Metabolic Syndrome: Clinical Research \& Reviews. $\underline{\mathrm{C}}$

Kiran, D.R. (2017). Total Quality Management Key Concepts and Case Studies. United Kingdom: Elsevier.

Laing, T. (2019). The economic impact of the Coronavirus 2019 (COVID-2019): Implicationsfor the mining industry. The Extractive Industries and Society. https://doi.org/10.1016/j.exis.2020.04.003

Ramezani, A.R. \& Mahdloo, M. (2014). Lean and its basic components. Academic Journal of Research in Business \& Accounting, 2(4): 36-45.

Sobieralski, J.B. (2020). COVID-19 and airline employment: Insight from historical uncertainty shocks to the industry. Transportation Research Interdisclipinary Perspectives. http://dx.doi.org/10.1016/j.trip.2020.100123

Sugiyono. ( 2017). Metode Penelitian Kualitatif. Bandung: Alfabeta.

Thangarajoo, Y. \& Smith, A. ( 2015). Lean Thingking: An Overview. Industrial Engineering \& Management, 4(2): 1-5. http://dx.doi.org/10.4172/2169-0316.1000159

Zambrano-Monserrate, M.A., Ruano, M.A., Sanchez-Alcalde, L. (2020). Indirect effects of COVID-19 on the environment. Science of Total Environment. https://doi.org/10.1016/j.scitotenv.2020.138813 
Appendix 1 Profiles of Survey Respondents Stage 1

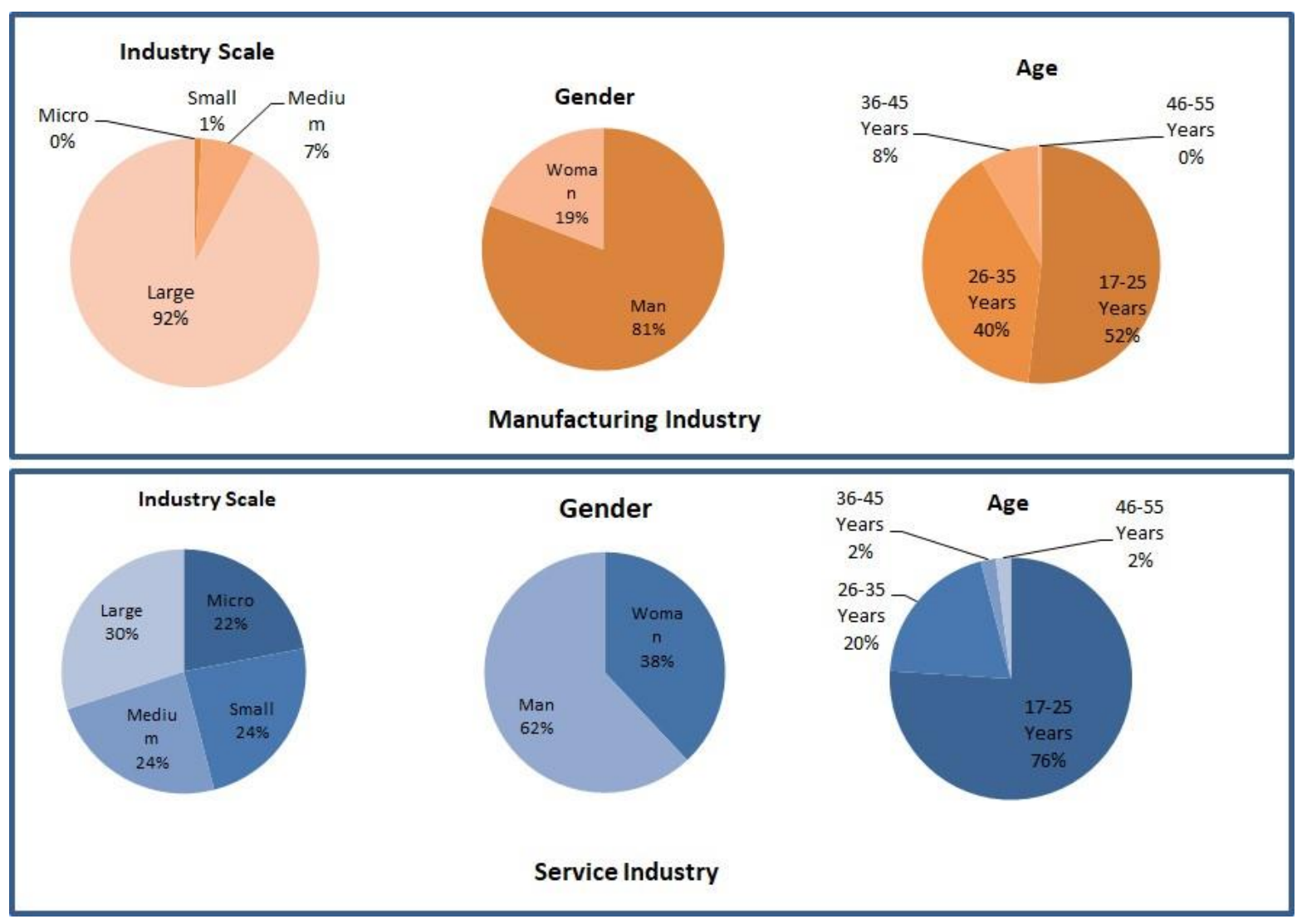

Appendix 2 Results of Stage 1 Questionnaire Processing
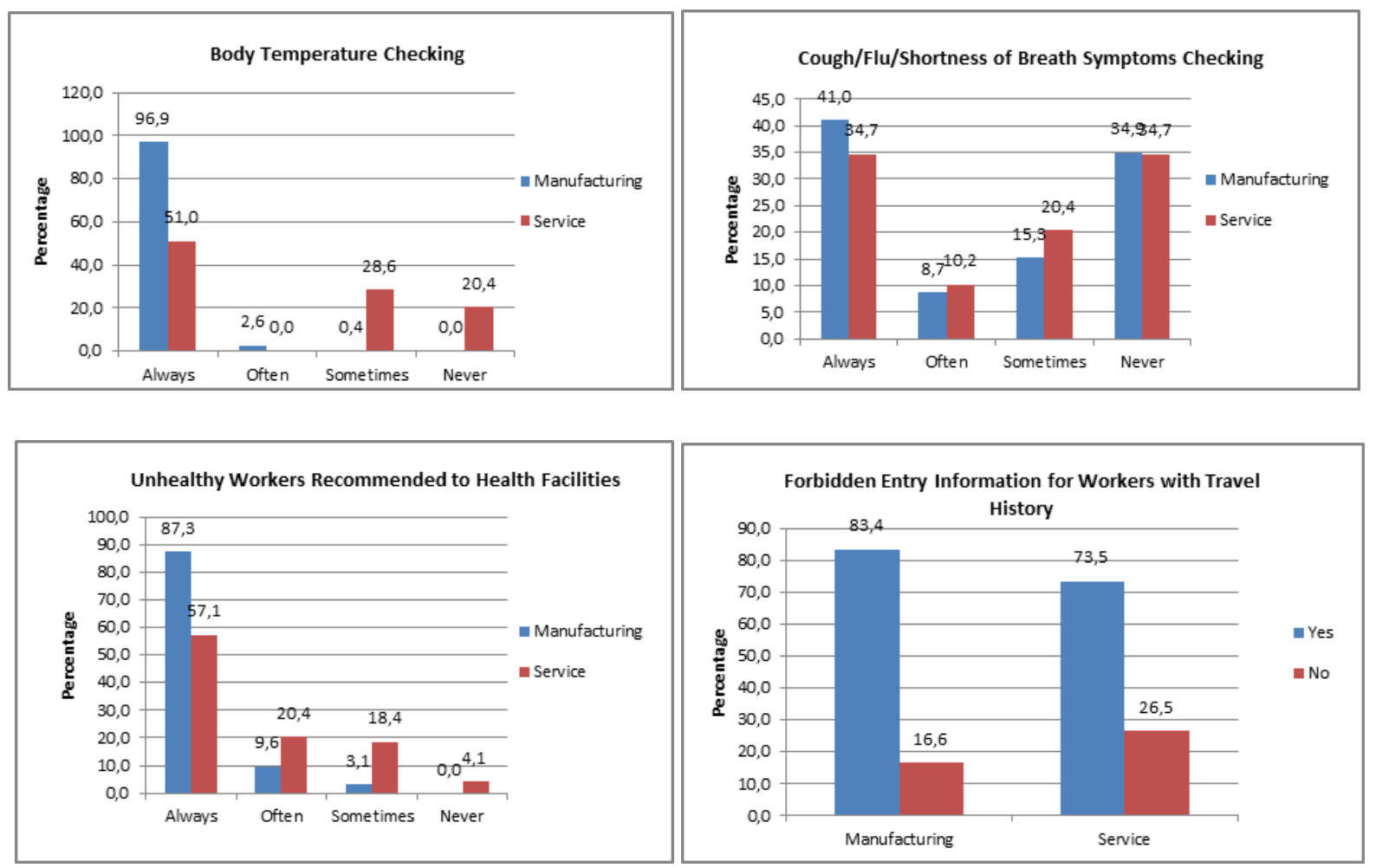

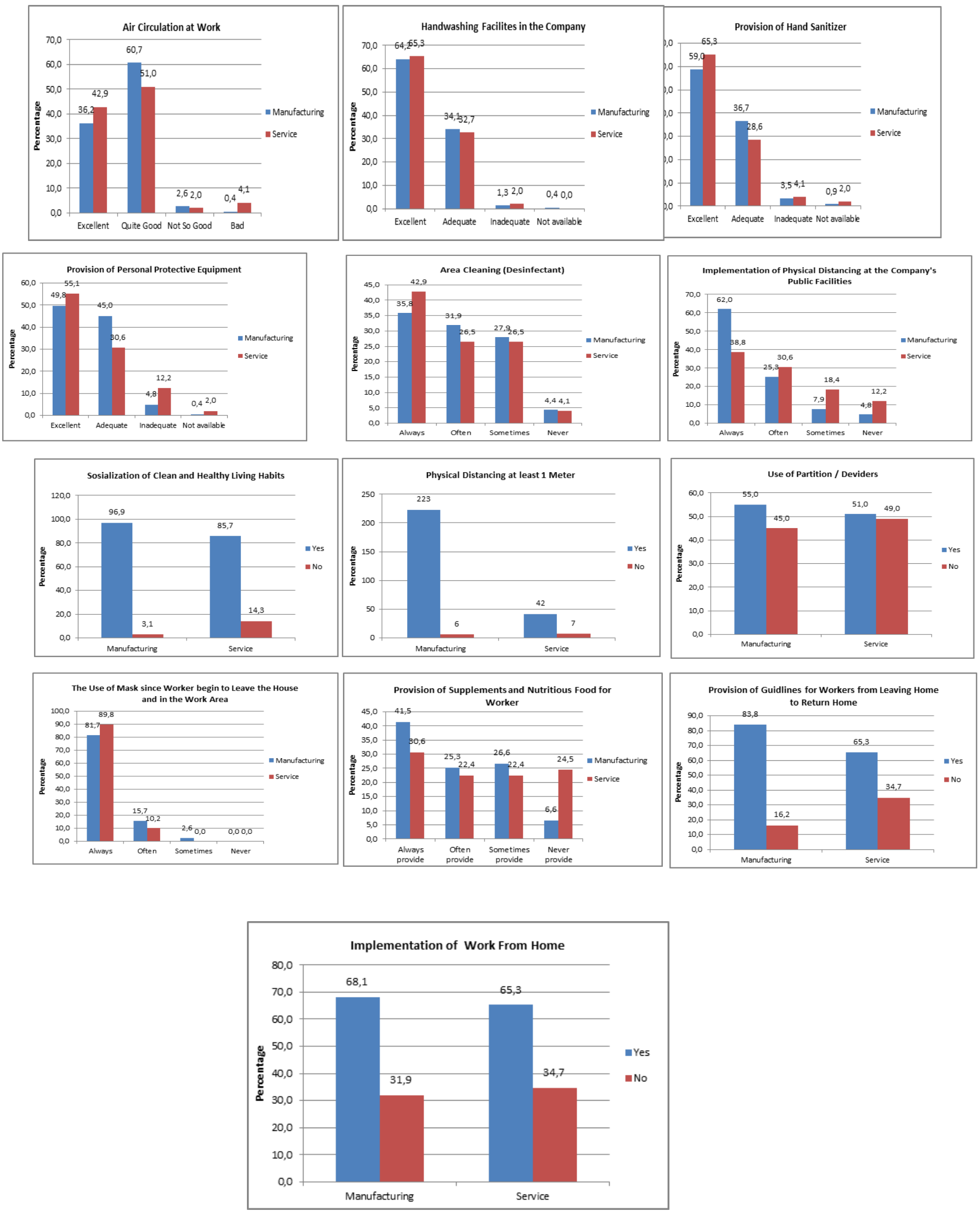